\title{
Education as an Instrument for Achieving Social Justice and Good Governance
}

\author{
Unwana D. Uyanga \\ Inemesit E. Emana
}

Department of Educational Foundations, Guidance and Counselling, Faculty of Education, University of Uyo Email: unwanamitchelle@yahoo.ca; inemesit.emana@gmail.com

\author{
Doi:10.5901/jesr.2016.v6n2p205
}

\begin{abstract}
This paper is an attempt to alert educators and education stake holders to the viability of using education as an instrument for achieving social justice and good governance. The paper, utilising the literature review methodology, begins by highlighting the relationship between social justice and good governance and proceeds to examine the instrumental value of education. The paper further draws on current literacy on education, social justice and good governance to show how education may effectively be used to propagate the ideals of social justice and promote good governance.
\end{abstract}

Keywords: Social justice; Good governance; Education; Philosophy of Education.

\section{Introduction}

Social justice and Good Governance are twin concepts that are intricately linked in the promotion of the wellbeing of human beings. Social justice implies having structures put in place through which individuals can key in to achieve their innate potentials. Good governance on the other hand deals with a series of processes in which a people entrusted with overseeing the affairs of the state evolve policies which aim at qualitatively and quantitatively improving the lives of the citizens they represent. Such policies target and embody promoting inclusiveness, respect for the rule of law, transparency, accountability and responsiveness. Social justice brings about good governance and in turn good governance makes social justice thrive in society; making it impossible for one to exist without the other. These elements (social justice and good governance) exist to promote and protect the rights and dignity of human beings and the need for human beings to blossom in just and free societies where government is responsive to the needs of the citizens and in turn, the citizens work for their good and that of the society.

Education is defined by Kalusi (2010) as involving all aspects of the society from the material conditions to the cognitive and psychological states of the individuals with a view to promoting knowledge and understanding. It is a deliberate process of inculcating individuals into social life through the transmission of knowledge, acquisition of relevant skills and moulding of character by accepting a value system through formal and informal social agencies to enhance the survival skills of individuals in their society and promote development.

In the words of Aminigo and Nwaokugha (2010), education is a major catalyst for sustainable development of human resources upon which the sustainable existence and continuous development of the state is based. It is a fundamental human right, as established by the United Nations Declaration (Charter) of 1945. Okafor (2006) considers the right to education as an inalienable right humans have on the basis of their humanity.

\section{Purpose of Study}

The purpose of this article is to examine how education may be utilized in the furtherance of social justice and good governance. The objective is to a highlight the instrumental value of education and show how good governance and social justice may be promoted through education; education focused on inculcating the ideals of social justice in the learners and promoting the quest for good governance.

\section{Methodology}

This paper employs the literature review methodology. Friedman (2006) and Keeble-Allen and Armitage (2008) maintain 
that the literature review methodology allows the researcher to synthesize previous and current knowledge such that new insights emerge and is based on the basic assumption that knowledge accumulates and that we learn from and build on previous studies. This work therefore is a synthesis of current literature on education, good governance and social justice from various publications. The choice of this method is based on the objective to show clearly, through a synthesis of existing knowledge, how education could effectively propagate the ideals of social justice and good governance.

\section{Assessing the Instrumental Value of Education}

Education is a goal oriented activity. As a process, it aims at the following as posted on http://www.education.nic... :

$\checkmark$ Individual development through enlightenment of the head and heart of men and the illumination of consciousness for the all-round development of individual personality. Education therefore, must aim at enabling individuals to attain the greatest possible harmony for the fullest possible development of human potentials and capacities.

$\checkmark$ Social and National Development through promoting essential values and commitments that are laid down especially in the constitution.

$\checkmark$ Social transformation through enabling men and women initiate and bring about desirable changes in the society. These changes must be in line with modernization practices by making people become more scientific and technological in their approaches to solving problems and general issues of daily life.

$\checkmark$ Acquisition of Values by promoting spiritual, moral, cultural and social values. These values include tolerance, cooperation, goodwill, respect for others, responsibility, integrity, creativity, optimism, service to the poor etc.

Education generally aims at self-realization, better human relations, individual and national efficiency, effective citizenship, national consciousness, national unity as well as towards social, cultural, economic, political, scientific and technological progress (Kalusi, 2010).

Education offers numerous benefits to individuals and societies. These benefits include:

$\checkmark$ Promoting intellectual reasoning and enhancing the rationality of men.

$\checkmark$ Guiding men's interaction and conducts in civilized societies.

$\checkmark$ Making men easier to govern but difficult to enslave and colonize as it allows them to understand laws and know their rights.

$\checkmark$ Making men choose to live happier; more productive and fulfilled lives in a relatively comfortable and qualitative society.

$\checkmark$ Promoting the inner desire for development by fostering the improvement of conditions of living.

$\checkmark$ Promoting the social and economic wellbeing of individuals and making them goal oriented and goal achieving in a highly competitive and diverse world. (Uyanga, 2014)

$\checkmark$ When an individual and indeed members of a society are educated, there is a high tendency to translate these principles acquired to tangible elements that can bring about value re-orientation and position the nation for positive development to take place.

Education as identified by Shively (2005) is the most basic service that most governments are expected to offer to their people. Farley (2010) opines that education increases feelings of relative deprivation as people become aware of inequalities and unfair treatment. This underscores the importance of education because it is an instrument to lead people out of the clutches of ignorance and into the realm of enlightenment. With enlightenment comes knowledge and with a substantial amount of knowledge come breakthroughs, creativity and innovations made with the use of one's capacity to reason.

\section{Elements of Social Justice and Good Governance}

Social justice is based on principles of equality and solidarity that recognize and value human rights and the dignity of the human person while good governance is the ethical and accountable use of authority at various levels of social existence. There are eight elements of social justice according to Bradley (2010):

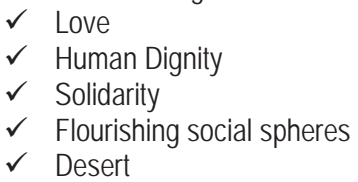




\section{$\checkmark$ Reciprocity \\ $\checkmark$ Need and \\ $\checkmark$ Equality}

Justice, in the words of Nwabueze (1993) in Uyanga (2014), is a virtue which requires that a person who is to take decisions or actions affecting other persons regards the people's interest as he would regard his own while avoiding all forms of bias or partiality. If this is really to be in societies, then these elements as stated above must be present. Society thrives when the common good of all overrides the personal interest of one or a few individuals. Relationships must exist in societies for them to stand and for these relationships to succeed, they must be characterized to a very large extent by love, respect and dignity of the human person, must pursue a common purpose, thrive in a conducive atmosphere which supports life and growth both qualitatively and quantitatively, give each man what is rightfully his due, be able to give and take as situations arise and demand, have their needs met and also be given equal rights and treatments as befits their status.

There are also eight elements of good governance as listed by The United Nations Economic and Social Commission for Asia and the Pacific (UNESCAP). These are:
$\checkmark$ Participatory
$\checkmark$ Consensus Oriented
$\checkmark$ Accountable
$\checkmark$ Transparent
$\checkmark$ Responsive
$\checkmark$ Equitable and Inclusive
$\checkmark$ Effective and Efficient and
$\checkmark$ Follows the Rule of Law

These eight elements must be practiced in societies as members of the society must be involved in decision making processes in governance either directly or indirectly through representative bodies, different constructive views of individuals must be incorporated to move the society forward, representatives of the commonwealth (sovereignty) must be able to be accountable to promote a sense of belonging, leaders must be transparent and open and must be responsive to the yearnings of the followers, inclusiveness and equitable distribution of resources must be promoted. Anyiam-Osigwe (2011), quoting a statement credited to Martin Luther King Jr., maintains that no greater tragedy can befall a nation than to leave millions of people with a feeling that they have no stake in their society. Hence, there must be effective and efficient representation of chosen authority, and all these must follow a legal framework put in place. Moreover, such legal framework must reign supreme and form the basis on which the political system runs (Barnes, 2012).

The people being governed matter in any society and for any society that is willing to develop in every ramification must enshrine the elements of social justice and good governance as guiding principles to lay down the pathway for success.

\subsection{Social Justice and Good Governance}

Irrefutably, social justice plays a vital role in enhancing good governance. Good governance would be elusive if the governed are passive and non-supportive; hence, the imperative of social justice in ensuring good governance. Uyanga (2014) shows that social justice can contribute to good governance in the following ways:

$\checkmark$ Protection of human rights and dignity of persons: This can be achieved by enforcing an already structured impartial set of laws that are put in place to protect human rights and dignity of persons from being violated. Human rights are many and they include amongst others, a right to life. Every individual is entitled to life and for this life to be lived to the fullest, the environment which the individual depends on for survival and all other relationships which sustain a peaceful coexistence and promote growth must be encouraging and supportive. These elements of survival must be continually renewed for the overall welfare and sustenance of this right. This is where social justice comes in, because with the realization of this right, individuals can rightly choose representatives of the sovereignty who would pursue goals that reflect their needs and desires

$\checkmark$ Equality or Impartiality in the treatment of every individual: The crux of equality here does not refer to making human beings equal as they differ in their needs, capacities and other features but in making opportunities available for everyone to have equal opportunity and treatment in the society. Again, the tenets of social justice are binding because it negates abuse and dehumanization of individuals. Therefore every partial 
treatment that may arise out of nepotism, ethnicity and other frivolities should be downplayed in favour of who may qualify rather than who I know.

$\checkmark$ Respect for the rule of law: The law must be free from favouritism and bias and must operate with the same standard irrespective of persons. The laws are made to guide conduct of members of society and therefore should indeed be upheld by all members. This is closely linked to the point on equality and impartiality in the treatment of men. This is because if the rule of law is truly a standard for all, then it (the rule of law) will pride itself in being equal and impartial.

$\checkmark$ Solidarity and Inclusiveness: Participation at all levels of social existence; economically, politically, culturally, socially and otherwise must be embraced and practiced. Individuals must be part of society as society is also part of them. Society cannot grow if the parts that make up the whole society are dysfunctional and unorganized. Togetherness as a goal must be pursued vigorously and with this, people become involved with what is happening in their societies and not just overwhelmed by changes that take place. Members of the society when they come together can become the agents of change they desire. This can be seen in the past elections held in Nigeria on the $28^{\text {th }}$ of March and $11^{\text {th }}$ April, 2015. With this new wave, chosen representatives already have realized that they must be accountable to those who elected them and indeed use public offices to serve the public as opposed to being served by the public which has been the order of the day.

$\checkmark$ The promotion of a just state: When the common good which is a bilateral relationship between Nigeria and Nigerians and between the country and its citizens (Eboh, 2001) is promoted and systematically pursued in a society; it gives the opportunity for justice to flourish and for citizens to be happy and live fulfilled lives in their society that cares about them. Justice is an ideal and it takes individuals with firm courage to stand up and work for it. A just state guarantees fairness or rightness in the treatment of other people (Aminigo and Nwaokugha, 2013). A just state is established on the moral principles of mutual consideration of everyone's interest. Every member of the society is important for the sake of justice and therefore cannot be abused.

\section{Promoting Social Justice and Good Governance through Education}

Education has been identified as a tool par excellence for promoting national development (Federal Government of Nigeria, 2004). The huge investments made by some societies in education have been justified by the reason that an educated population is able to contribute to the socio-economic development of the society as a whole (Schlutz 1980 in Uyanga, 2014). Education widens the capabilities of individuals and socializes them to live a more decent and disciplined life capable of making them acceptable members of their society and state (Aminigo and Nwaokugha, 2009). Educated members of the society stand a greater chance of being able to make positive contributions that will translate into the development of themselves and the society in which they live. Educated individuals know what social justice and good governance are and what their presence in the society can bring about for the common good of all and therefore pursue these values vigorously to promote the "greatest good" which Plato has defined as Justice (The Republic, 1990). Education will lead to the three core indices of development being present in the society. These indices, as identified by Todaro and Smith (2009), are:

$\checkmark$ Sustenance: The ability to meet basic needs

$\checkmark$ Self-esteem: Having self-worth and self-respect, and

$\checkmark$ Freedom from servitude: The ability to choose and be emancipated from oppressive institutions and dogmatic beliefs.

Education will encourage sustainable development through empowerment, cooperation, equity and security. Education will promote the achievement of the Millennium Development Goals (MDGs) through the NEEDS, SEEDS and LEEDS initiatives and this will indeed make it the needed instrument to achieve the national goals. The National Policy of Education (FGN, 2013) lists these national goals to include the building of:

$\checkmark$ a free and democratic society;

$\checkmark$ a just and egalitarian society;

$\checkmark$ a united, strong and self-reliant nation;

$\checkmark$ a great and dynamic economy; and

$\checkmark \quad$ a land full of bright opportunities for all citizens.

Education upholds the need for the following:

$\checkmark$ Enlightening individuals on the rudiments of social life and the fundamental need for social justice and good 
governance to guide their conducts.

$\checkmark$ Creating awareness on various human rights and the need to guard against their abuse.

$\checkmark$ Making citizens understand how to make responsible demands from their elected representatives through sensitizing them on how to choose leaders who can make social justice and good governance norms in the society.

$\checkmark$ Removing the veil of ignorance which blindfolds citizens into thinking they are passive actors in transformation processes in society.

$\checkmark$ Creating opportunities for members of the society to participate in nation building.

$\checkmark$ Developing competencies, skills and talents that will enable citizens develop themselves and their societies.

$\checkmark$ Inculcating the values of morality, fairness, equity and justice as sound principles that must guide the interactions of citizens in society etc.

With what education encourages and upholds in the society, it is important for members of a society to be educated not just for literacy purposes but to become morally conscious and rational beings who can make use of their abilities to think, to see, feel, to taste and to embark on sustainable practices that can generally improve conditions of living and make society more conducive for promotion of the good of man.

Education can become an instrument for promoting social justice and good governance when it becomes:

$\checkmark$ Available to all

$\checkmark$ A means to an end and not an end in itself

$\checkmark$ A carrier of the gene of democracy, human and national development.

\subsection{Making education available to all}

Article 26 (1) of the United Nations Declaration as quoted in Musa (2011) states that:

Everyone has a right to education. Education shall be free, at least in the elementary and fundamental stages. Elementary education shall be compulsory. Technical and fundamental education shall be made generally available and higher education shall be accessible to all, on the basis of merit.

When education is made available to all persons irrespective of cultural, ethnic or religious background, a solid footing for building the human person and the nation at large is established. No society can even foresee development without investing heavily in its members and the best investment that can be made is the investment in education because of some of its fruits as discussed above. Making education available to all enables individuals to learn to know, learn to do, learn to live together and learn to develop skills which are the UNESCO expectations of quality education as pinned down by Delors, in Amanchukwu (2011). This will definitely play a vital role in sensitizing the citizenry on the fact that their society cherishes and values them. When this message is passed across, any self-conscious individual who has benefited from the society will want to contribute enormously to the society that made him. Making education available to all promotes the welfare of citizens as they become aware of ways to protect and promote qualitative living by protecting the dignity of man and is also able to form a strong opposition to whatever forces may want to arise and cause the dehumanization of the human person.

\subsection{Education as a means to an end and not an end in itself}

Education is the most important channel of social mobility (Aminigo, 2003). With education, individuals are sure of upward mobility in their societies. As a means to an end, education:

$\checkmark$ Inculcates literacy in those committed to its process,

$\checkmark$ Develops skills and competencies in individuals,

$\checkmark$ Molds and shapes the character of individuals,

$\checkmark$ Makes individuals conscious of the world around them, and

$\checkmark$ Inculcates dignity and respect for the worth of the human person.

As a means to an end, in addition to the above, education develops the intellectual faculties of people and makes them disposed to harnessing available opportunities while also helping them to turn these opportunities into tangible visions that can lead to the creation of wealth and comfort. As a means to an end, education enables individuals to develop innate potentials which ordinarily would remain latent and dormant. As a means to an end, education makes the difference between the "rich" and the "poor", "the man" and "the animal", that is those operating at the appetitive level and 
"the developed" and "underdeveloped".

\subsection{Education as a carrier of the gene of democracy and development}

Democracy is a set of values which include rule by elected representatives, universal adult suffrage and respect for human rights (Eberinwa, Oparaku \& Ugorji, 2012). In a democracy, the individual and the society are organic to each other, that is, each element is alive to its responsibility to the other party. A democracy has three basic features as outlined by Osiwa in Eberinwa et al (2012). These are:

$\checkmark$ Opportunity for the common man

$\checkmark$ Equality of rights

$\checkmark$ Discussion and Change

As a carrier of the gene of democracy, education must ensure it promotes freedom, justice, fairness, equality, morality and openness while also giving opportunities for individuals to make use of their initiatives and creativity. As an instrument of human development, education equips the human person with capacities that will enable him live and function effectively in his environment by making choices from given alternatives that will lead to the attainment of predetermined goals and objectives. As an instrument of national development, education is an instrument for achieving the goals of the national policy as enunciated in section one of the policy documents of 2013. Education through the Basic level to Post-Basic level and Career Development and even up to Higher levels aims at making the individual a morally conscious, socially competent and functional member of society. That is, a person who is able to contribute meaningfully and successfully, qualitatively and productively to the development of the nation.

In order to promote social justice and good governance in Nigeria, education would focus on:

$\checkmark$ The eradication of extreme poverty and hunger in the Nigerian nation

$\checkmark$ Equal treatment of every citizen regardless of ethnic, cultural or religious affiliations

$\checkmark$ Gender equality

$\checkmark$ Participation and Inclusiveness in social life and

$\checkmark$ Justice for all.

\section{Conclusion}

This paper has examined in depth how education can be used as an instrument to promote social justice and good governance in the Nigerian society. Indeed, a lot of light has been shed on the value of having the elements of social justice and good governance present in the Nigerian nation. In a society where these elements are allowed to flourish, life for every citizen becomes more secure and appreciated as against abuse of human rights and dignity of persons, abuse of public office etc which truncates any developmental effort a nation may want to embark on. The best investment a nation can make as has previously been highlighted is in the education of its citizens. This, as shown in this paper; owes to the fact that education is the surest way to make individuals aware of their rights, how to protect their rights and how to make legitimate demands of their elected representatives.

\section{References}

Aims and Objectives of Education (n.d). Retrieved July 26, 2011, from http://www.education.nic.m//cd50years/gt/gf/otgfo201.html Amanchukwu, R. (2011). The Challenges of Quality Education and Good Governance in Developing Economy. African Journal of Education and Technology, 1 (3) 103-110

Aminigo, I. M. (2003). Educational Philosophy and National Development. Buguma, Rivers State: Hanging Gardens Publishers

Aminigo, I. M and Nwaokugha, D. O. (2009). Achieving Sustainable Environment through Curriculum and Pedagogical Innovations. In Oguzor, N. S. and Adebola, H. E (Eds) Education, Development and the Changing Environment. Spain: Granada

Aminigo, I. M and Nwaokugha, D. O. (2010). Education and Challenges of Environmental Justice in Nigeria. Trends in Educational Studies (TRES). Journal of the Institute of Education, University of Port Harcourt, 5 (1\&2) 49-67

Aminigo, I. M and Nwaokugha, D. O. (2013). An Advanced Introduction to Philosophy of Education. Uniport, Choba: Zelta Research Consult

Anyiam-Osigwe, K (2011, January 10). Politics and the Nigerian Dream. The Punch Newspaper p. 64

Barnes, A. (2012). The Rule of Law as a tool for Sustainable Democracy in Africa. International Bi-lingual Journal of Anti-Corruption, Law, Humanities, Social Sciences and Developmental Studies (IBJACLHSSDS), 3 (1) 120-124

Bradley, A. (2010, May 4). The Eight elements of Social Justice. Retrieved June 14, 2011 from http://www.bradley.chattablogs.com/ archives/2010/05/the-8-elements.html 
Eboh, M. P. (2001). Dialogue, Democracy and Morality. Owerri, Nigeria: Springfield Publishers Ltd

Farley, J. E. (2010). Majority-Minority Relations (6 ${ }^{\text {th }}$ ed). New York: Prentice Hall

Federal Government of Nigeria (2004). National Policy on Education. Lagos: Nerdc Press

Federal Government of Nigeria (2013; $6^{\text {th }}$ ed). National Policy on Education. Lagos: Nerdc Press

Friedman, L. W. (2006). Writing the literature survey paper. Retrieved from www.cisnet.baruch.cuny.edu/friedman/rm/litreview.htm

Kalusi, J. I. (2010). The Relevance of Philosophy of Education in National Development. Nigerian Journal of Educational Philosophy (njep), 6 (1) 76-92

Keeble-Allen, D., \& Armitage, A. (2008). Undertaking a structural literature review or structuring a literature review: Tales from the field. Electronic Journal of Business Research Methods, 6 (2), 103-114.

Musa, C. N. (2011). Deregulation of Education for Increased Access to Appropriate Education for the Girl-Child. Journal of Education in Developing Areas (JEDA), 19 (2) 185-197

Okafor, F. C. (2006). Philosophy of Education and Third World Perspective (5 $5^{\text {th }}$ ed). Port Harcourt: Odomezie Kris \& Company

Shively, W. P (2005). Power Choice: An Introduction to Political Science (9th ed). New York: McGraw Hill

Todaro, M. P and Smith, S. C. (2009). Economic Development (10th ed). Harlow, England: Pearson Education Limited

Uyanga, U. D. (2014). Social Justice and Good Governance in Nigeria: Implications for Education. An Unpublished Ph. D Dissertation submitted to the Department of Educational Foundations, University of Port Harcourt. 
